Research paper

\title{
Molecular detection of Hepatozoon spp. in domestic dogs and wild mammals in southern Pantanal, Brazil with implications in the transmission route
}

\author{
Keyla Carstens Marques de Sousa ${ }^{a}$, Marina Pugnaghi Fernandes ${ }^{a}$, \\ Heitor Miraglia Herrera $^{\mathrm{b}}$, Jyan Lucas Benevenute ${ }^{\mathrm{a}}$, Filipe Martins Santos ${ }^{\mathrm{b}}$, \\ João Bosco Campos ${ }^{\mathrm{b}}$, Thiago Fernandes Martins ${ }^{\mathrm{d}}$, \\ Paulo Henrique Duarte Cançado ${ }^{g}$, Rosangela Zacarias Machado ${ }^{a}$, \\ Marcos Rogério André ${ }^{a, *}$

\footnotetext{
${ }^{a}$ Faculdade de Ciências Agrárias e Veterinárias/Universidade Estadual Paulista, UNESP, Jaboticabal, SP, Brazil

b Universidade Católica Dom Bosco, Campo Grande, MS, Brazil

c Universidade Federal da Paraíba, Laboratório de Ecologia Animal, Rio Tinto, PB, Brazil

d Universidade de São Paulo, Faculdade de Medicina Veterinária e Zootecnia, São Paulo, SP, Brazil

e Laboratório de Parasitologia, Instituto Butantan, São Paulo, SP, Brazil

${ }^{\mathrm{f}}$ Universidade Federal de Mato Grosso do Sul, Campo Grande, MS, Brazil

${ }^{g}$ Embrapa gado de corte, Campo Grande, MS, Brazil
} Fabiana Lopes Rochac ${ }^{c}$, Wanessa Teixeira Gomes Barreto ${ }^{\mathrm{b}}$, Gabriel Carvalho Macedo ${ }^{\mathrm{b}}$, Pedro Cordeiro Estrela de Andrade Pinto ${ }^{c}$, Darci Barros Battesti ${ }^{e}$, Eliane Mattos Piranda ${ }^{\mathrm{f}}$,

\section{A R T I C L E I N F O}

\section{Article history:}

Received 11 October 2016

Received in revised form 7 February 2017

Accepted 20 February 2017

\section{Keywords:}

Hepatozoon spp

Ticks

Wild mammals

Dogs

Phylogenetic analysis

Brazil

\begin{abstract}
A B S T R A C T
Hepatozoon parasites comprise intracellular apicomplexan parasites transmitted to vertebrate animals by ingestion of arthropods definitive hosts. The present work aimed to investigate the occurrence of Hepatozoon spp. in wild animals, domestic dogs and their respective ectoparasites, in southern Pantanal region, central-western Brazil, by molecular techniques. Between August 2013 and March 2015, 31 coatis (Nasua nasua), 78 crab-eating foxes (Cerdocyon thous), seven ocelots (Leopardus pardalis), 42 dogs (Canis lupus familiaris), 110 wild rodents ( 77 Thichomys fosteri, 25 Oecomys mamorae, and 8 Clyomys laticeps), 30 marsupials (14 Thylamys macrurus, 11 Gracilinanus agilis, 4 Monodelphis domestica and 1 Didelphis albiventris), and 1582 ticks and 80 fleas collected from the sampled animals were investigated. DNA samples were submitted to PCR assays for Hepatozoon spp. targeting 18S rRNA gene. Purified amplicons were directly sequenced and submitted to phylogenetic analysis. A high prevalence of Hepatozoon among carnivores ( $C$. thous [91.02\%], dogs [45.23\%], N. nasua [41.9\%] and L. pardalis [71.4\%]) was found. However, ticks and fleas were negative to Hepatozoon PCR assays. By phylogenetic analysis based on $18 \mathrm{~S}$ rRNA sequences, Hepatozoon sequences amplified from crab-eating foxes, dogs, coatis and ocelots clustered with sequences of $H$. canis, H. americanum and $H$. felis. The closely related positioning of Hepatozoon sequences amplified from wild rodents and T. macrurus marsupial to Hepatozoon from reptiles and amphibians suggest a possible transmission of those Hepatozoon species between hosts by ectoparasites or by predation. Hepatozoon haplotypes found circulating in wild rodents seem to present a higher degree of polymorphism when compared to those found in other groups of animals. Although rodents seem not to participate as source of Hepatozoon infection to wild carnivores and domestic dogs, they may play an important role in the transmission of Hepatozoon to reptiles and amphibians in Pantanal biome.
\end{abstract}

(c) 2017 Elsevier B.V. All rights reserved.

\section{Introduction}

* Corresponding author at: Laboratório de Imunoparasitologia, Departamento de Patologia Veterinária, Faculdade de Ciências Agrárias e Veterinárias Júlio de Mesquita Filho (UNESP), Campus de Jaboticabal, Via de Acesso Prof. Paulo Donato Castellane, s/n, Zona Rural, CEP: 14884-900, Jaboticabal, São Paulo, Brazil.

E-mail addresses: mandre.fcav@gmail.com, marcos_andre@fcav.unesp.br (M.R. André).

http://dx.doi.org/10.1016/j.vetpar.2017.02.023

0304-4017/@ 2017 Elsevier B.V. All rights reserved.
Hepatozoon spp. are apicomplexan parasites that infect a wide variety of vertebrate hosts, which play a role as intermediate hosts and acquire infection through the ingestion of arthropod definitive host containing oocysts (Smith, 1996). Additionally, other routes of 
transmission, such as the predation of infected vertebrates containing Hepatozoon cysts in their tissues (Johnson et al., 2007) and transplacental transmission (Baneth et al., 2013), have been described.

Regarding the occurrence of Hepatozoon spp. in wild and captive animals in Brazil, the protozoa has been so far molecularly detected in crab-eating foxes (Cerdocyon thous) (André et al., 2010; Almeida et al., 2013); bush dogs (Speothos venaticus) (André et al., 2010); maned wolf (Cerdocyon brachyurus); ocelots (Leopardus pardalis) (Metzger et al., 2008; André et al., 2010); littlespotted-cats (Leopardus tigrinus) (André et al., 2010); yagourandi (Puma yagouaroundi), pumas (Puma concolor); rodents (Akodon sp., Oligoryzomys nigripes, Oligoryzomys flavescens, Calomys callosus) (Demoner et al., 2016; Wolf et al., 2016); rattlesnake (Crotalus durissus terrificus) (O'Dwyer et al., 2013); crocodiles (Caiman yacare) (Viana et al., 2010); lizards (Hemidactylus mabouia, Phyllopezus periosus, Phyllopezus pollicaris) (Harris et al., 2015); and anuran amphibians (Leptodactylus chaquensis, Leptodactylus podicipinus) (Leal et al., 2015).

Although Hepatozoon infections in wild animals are usually subclinical (Kocan et al., 2000; Metzger et al., 2008), some studies associated the Hepatozoon infection with the presence of clinical disease in coyotes (Kocan et al., 2000; Garrett et al., 2005), mortality in hyenas (East et al., 2008) and necrotizing inflammatory lesion in unnatural reptilian hosts (Wozniak et al., 1995). Moreover, Hepatozoon spp. may be a potential pathogen and an opportunistic parasite in immunocompromised animals or if occurring in concomitant infections (Davis et al., 1978; Baneth et al., 1998; Kubo et al., 2006). For that reason, there is a need to assess the distribution of Hepatozoon spp. in free-living animals, especially for endangered or elusive, free-living host species that are difficult to sample (Wobeser, 2007). Furthermore, large-scale parasite screening has the potential for determining the distribution of similar lineages in different hosts, providing information on parasite transmission dynamics, which represents an important issue for endangered species (Fayer et al., 2004).

There is a lack of information on the vectorial competence of arthropods that may act as definitive hosts for Hepatozoon spp. in Brazil. Although Rhipicephalus sanguineus sensu lato (s. 1.) is considered the main biological vector for Hepatozoon canis (Smith, 1996), preliminary studies indicated that this tick species has little or no importance in the transmission of Hepatozoon sp. in Brazil (Demoner et al., 2013). Additionally, H. canis oocysts have been found in the hemocoel of Amblyomma ovale (Forlano et al., 2005) and Rhipicephalus (Boophilus) microplus (Miranda et al., 2011). Furthermore, the role of other invertebrate hosts in the transmission cycles of Hepatozoon sp. has been investigated. For instance, Watkins et al. (2006) observed oocysts of Hepatozoon sp. in Megabothris abantis fleas collected from rodents, suggesting the participation of this ectoparasite in the biological cycle of Hepatozoon sp.

The predation of paratenic hosts seems to be another important infection route for Hepatozoon spp. (Johnson et al., 2009). Sequences of Hepatozoon spp. obtained from rodents and wild canids in South Africa showed to be phylogenetically related, suggesting a potential for transmission by predation of rodents by foxes (Vulpes pallida) (Maia et al., 2014). Additionally, Hepatozoon genotype sp. detected in snakes (Python regius and Boa constrictor imperator) were closely related to sequences of Hepatozoon spp. obtained from rodents in North America (Sloboda et al., 2008; Allen et al., 2011). In Brazil, the prevalence of $H$. canis among domestic dogs in rural areas has showed to be higher than in urban areas. Although dogs from rural areas often roam the forests and probably predate Hepatozoon sp.-infected animals (O'Dwyer, 2011), the analysis of sequences obtained from wild rodents from an endemic area for $\mathrm{H}$. canis showed that wild rodent species in Brazil were infected with other
Hepatozoon species, rejecting the hypothesis that rodents act as reservoirs for $H$. canis in the state of São Paulo, southeastern Brazil (Demoner et al., 2016). However, monozoic cysts were found in the sampled rodents' tissues, suggesting that rodents may act as paratenic hosts for Hepatozoon spp. in Brazil (Demoner et al., 2016).

The aim of the present study was to investigate the occurence of Hepatozoon spp. in wild mammals and domestic dogs and their respective ectoparasites in the region of Pantanal, state of Mato Grosso do Sul, central-western Brazil.

\section{Material and methods}

The fieldwork was conducted at the Nhumirim ranch $\left(56^{\circ} 39^{\prime} \mathrm{W}\right.$, $18^{\circ} 59^{\prime} \mathrm{S}$ ), located in the central region of the Pantanal, municipality of Corumbá, state of Mato Grosso do Sul, central-western Brazil (Fig. 1). This region is characterized by a mosaic of semideciduous forest, arboreal savannas, seasonally flooded fields covered by grasslands with dispersed shrubs and several temporary and permanent ponds. The Pantanal is the largest Neotropical floodplain and it is well known for a rich biodiversity. Two well-defined seasons are recognized: a rainy summer (October to March) and a dry winter (April to September) (Alves et al., 2016).

Between August 2013 and March 2015, four field expeditions (August 2013, October 2013, August 2014 and March 2015) were performed. The free-ranging carnivores (C. thous, N. nasua and L. pardalis) were caught used a Zootech $^{\circledR}$ (Curitiba, PR, Brazil) model wire box live trap $(1 \times 0.40 \times 0.50 \mathrm{~m})$, which was made with galvanized wire mesh and baited with a piece of bacon every afternoon. Traps were armed during $24 \mathrm{~h}$ and checked twice a day. The animals were immobilized with an intramuscular injection of a combination of zolazepan and tiletamine (Zoletil $\left.{ }^{\circledR}\right)$ at dosages of $8 \mathrm{mg} / \mathrm{kg}$ for ocelots and $10 \mathrm{mg} / \mathrm{kg}$ crab-eating foxes and coatis. Blood samples were collected by puncture of the cephalic vein stored in Vacutainer ${ }^{\circledR}$ containing EDTA and stored at $-20^{\circ} \mathrm{C}$ until DNA extraction. Additionally, blood samples were collected from 42 domestic dogs, which were cohabiting the same studied area. In addition to this, blood smears were performed and fixed with methanol and stained with Giemsa ${ }^{\circledR}\left(\right.$ Giemsa $^{\circledR}$ stain, modified, Sigma-Aldrich, St. Louis, MO,USA).

Small mammals (rodents and marsupials) were captured using live traps $\left(\right.$ Sherman $^{\circledR}-$ H. B. Sherman Traps, Tallahassee, FL, USA and Tomahawk $^{\circledR}$ Tomahawk Live Traps, Tomahawk, WI, USA) baited with a mixture of banana, peanut butter, oat and sardines. Traps were set up for 7 consecutive nights along linear transects, placed on the ground at $10 \mathrm{~m}$ intervals and alternating between trap type in 2 field expeditions (August 2014 and March 2015). The total capture effort was 200 traps-nights, equally distributed between the 2 expeditions (August 2014 and March 2015). The identification of specimens was based on external and cranial morphological characters and karyological analyses, as previously described by Bonvicino et al. (2005). The animals were firstly anesthetized with an intramuscular injection of ketamine $(10-30 \mathrm{mg} / \mathrm{kg})$ associated with acepromazine $(5-10 \mathrm{mg} / \mathrm{kg}$ ) for rodents (proportion 9:1), or xylazine $(2 \mathrm{mg} / \mathrm{kg})$ for marsupials $(1: 1)$. After anesthesia, the animals were euthanized with potassium chloride, which dosis ranged from 75 to $150 \mathrm{mg} / \mathrm{kg}$ (Leary et al., 2013). Spleen samples were collected and stored in absolute alcohol (Merck ${ }^{\circledR}$, Kenilworth, Nova Jersey, USA). Animal handling procedures followed the Guidelines of the American Society of Mammalogists for the use of wild mammals in research (Sikes and Gannon, 2011). The project had permission from the Brazilian Government Environmental Agency (Brazilian Institute of Environment and Renewable Natural Resources) (IBAMA) (SISBIO licenses numbers 38145, 38787-2) and was also endorsed by the Ethics Committee of the FCAV/UNESP 


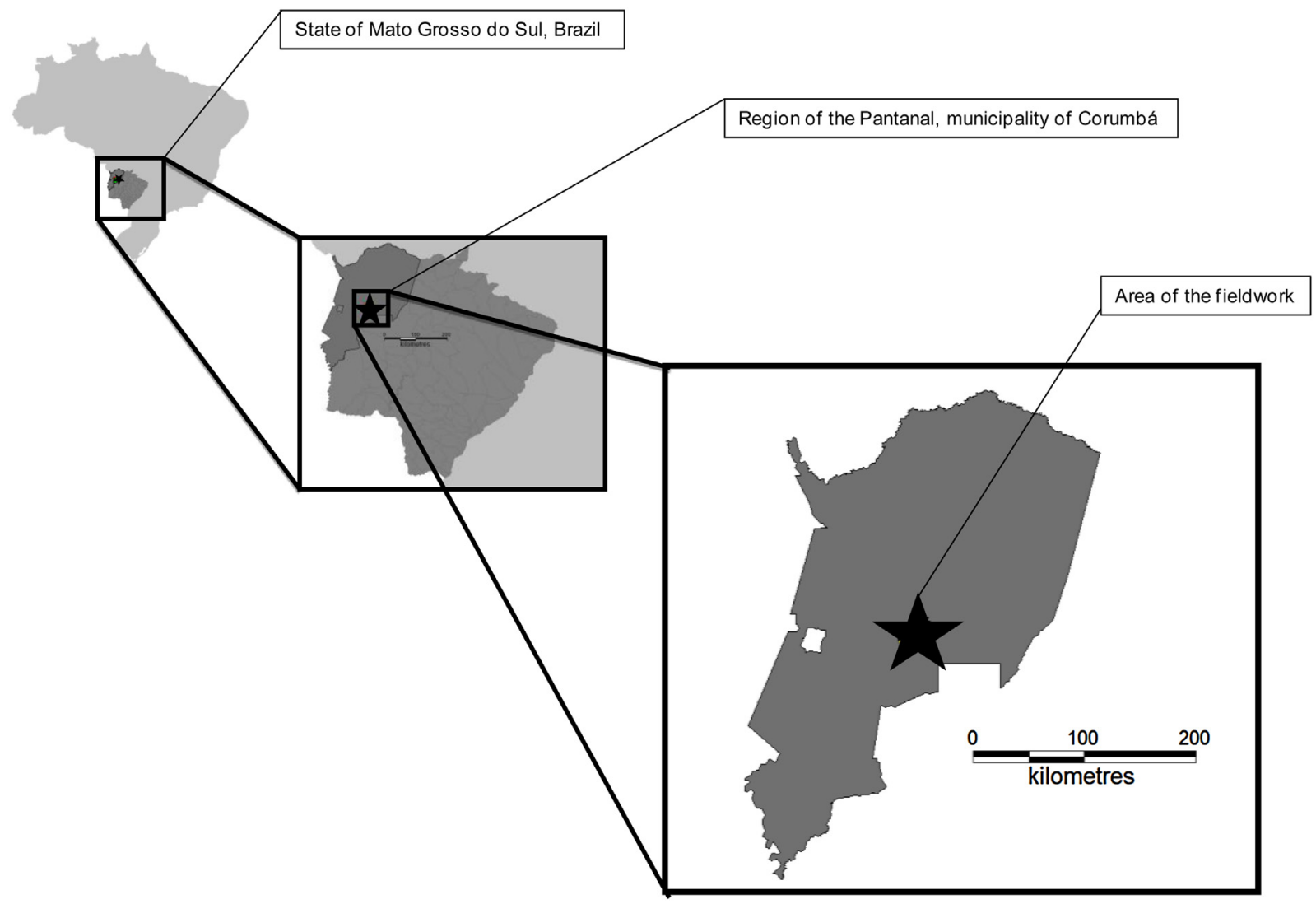

Fig. 1. Capture sites. Map of Mato Grosso do Sul State, central-western Brazil, showing the Pantanal region where animals samples were collected in the present study.

University (CEUA $-\mathrm{n}^{\circ}$ 006772/13), in accordance to Brazilian regulations.

Ticks and fleas found parasitizing the sampled animals were detected by inspection of the skin and carefully removed by forceps or manually. The specimens were stored in $100 \%$ alcohol (Merck $^{\circledR}$, Kenilworth, Nova Jersey, EUA) until identification using a stereomicroscope (Leica ${ }^{\circledR}$ MZ 16A, Wetzlar, Germany) and following taxonomic literature for adult tick genera (Guimarães et al., 2001; Martins et al., 2016), and Amblyomma nymphs (Martins et al., 2010). Amblyomma larvae could not be identified to the species level because there is insufficient literature available until now. The identification of fleas was performed following the dichotomous keys elaborated by Linardi and Guimarães (2000).

DNA was extracted from $200 \mu \mathrm{L}$ of each whole blood (wild carnivores and domestic dogs) and spleen (small mammals) samples using the QIAamp DNA Blood Mini kit $\left(\right.$ QIAGEN $^{\circledR}$, Valencia, CA, USA), according to the manufacturer's instructions. While ticks DNA extraction was processed in pools for nymphs (up to 5 individuals) and larvae (up to 10 individuals), the adults were processed individually. The fleas DNA extraction also was processed in pools consisting of up to five individuals. Ticks and fleas were macerated and prepared for DNA extraction, using the same kit before mentioned. DNA concentration and quality was measured using absorbance ratio between $260 / 280 \mathrm{~nm}$ (Nanodrop ${ }^{\circledR}$, Thermo Fisher Scientific, Waltham, MA, USA).

In order to verify the existence of amplifiable DNA in the samples, internal control PCR assays targeting the glyceraldehyde-3phosphatedehydrogenase (GAPDH) mammals gene (Birkenheuer et al., 2003), mitochondrial 16S rRNA ticks gene (Black and Piesman, 1994) and a fragment of the cytochrome c oxidase subunit I (cox1) coding for COX1 from fleas (Folmer et al., 1994) were performed. Two different PCR protocols were used aiming at amplifying differ- ent regions of 18SrRNA of Hepatozoon, based on Perkins and Keller (2001) and Ujvari et al. (2004) protocols (Table 1). Thus, the two Hepatozoon 18S rRNA sequences obtained by the two PCR protocols were concatenated in order to obtain a large 18S rRNA fragment $(1300 \mathrm{pb})$ to be used in phylogenetic analyses. DNA positive control was obtained from a naturally infected dog (Malheiros et al., 2016) and ultra-pure sterile water (Life Technologies ${ }^{\circledR}$, Carlsbad, CA, USA) was used as negative control.

The reaction products were purified using the Silica Bead DNA gel extraction kit (Thermo Fisher Scientific ${ }^{\circledR}$, Waltham, MA, USA). The sequencing of the two different regions of $18 \mathrm{~S}$ rRNA Hepatozoon spp. gene fragments of was carried out using the BigDye ${ }^{\circledR}$ Terminator v3.1Cycle Sequencing Kit (Thermo Fisher Scientific ${ }^{\circledR}$, Waltham, MA, USA) and ABI PRISM 310DNA Analyzer (Applied Biosystems ${ }^{\circledR}$, Foster City, CA, EUA) (Sanger et al., 1977).

The sequences obtained from positive samples were first submitted to a screening test using Phred-Phrap software version 23 (Ewing and Green, 1998; Ewing et al., 1998) to evaluate the electropherogram quality and to obtain consensus sequences from the alignment of the sense and antisense sequences. The BLAST program (Altschul et al., 1990) was used to analyze the sequences of nucleotides (BLASTn), aiming to browse and compare with sequences from international database (GenBank) (Benson et al., 2002). All sequences that showed appropriate quality standards and identity with Hepatozoon spp. were deposited in the international database Genbank. Samples showing positive results for both PCR protocols had their sequences concatenated, using the Fragment Merger software version 1 (Bell and Kramvis, 2013). The sequences were aligned with sequences published in GenBank using MAFFT software, version 7 (Katoh and Standley, 2013).

Phylogenetic inference was based on Bayesian (BI) and Maximum Likelihood (ML) methods. The Bayesian inference (BI) analysis 
Table 1

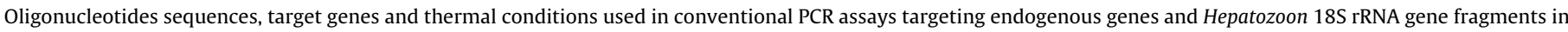
biological samples from wild mammals and domestic dogs, trapped and sampled, respectively, in southern Pantanal, state of Mato Grosso do Sul, central-western Brazil.

\begin{tabular}{|c|c|c|c|}
\hline $\begin{array}{l}\text { Oligonucleotides sequences } \\
\left(5^{\prime}-3^{\prime}\right)\end{array}$ & Target gene & Thermal conditions & References \\
\hline $\begin{array}{l}\text { GAPDH-F } \\
\text { (CCTTCATTGACCTCAACTACAT) }\end{array}$ & GAPDH/Mammals & $\begin{array}{l}95^{\circ} \mathrm{C} \text { for } 5 \mathrm{~min} \text {; } 35 \text { cycles of } \\
95^{\circ} \mathrm{C} \text { for } 15 \mathrm{~s}, 50^{\circ} \mathrm{C} \text { for } 30 \mathrm{~s} \text { and } \\
72^{\circ} \mathrm{C} \text { for } 30 \mathrm{~s} \text {; and final } \\
\text { extension of } 72^{\circ} \mathrm{C} \text { for } 5 \mathrm{~min} \text {. }\end{array}$ & $\begin{array}{l}\text { Birkenheuer et al. } \\
(2003)\end{array}$ \\
\hline
\end{tabular}

GAPDH-R

(CCAAAGTTGTCATGGATGACC)

16S + 1 (CTGCTCAATGATTTTT-

TAAATTGCTGTGG)

16SrRNA/Ticks

10 cycles of $92^{\circ} \mathrm{C}$ for $1 \mathrm{~min}$, $48^{\circ} \mathrm{C}$ for $1 \mathrm{~min}$ and $72^{\circ} \mathrm{C}$ for 1 min, followed by 32 cycles of $92^{\circ} \mathrm{C}$ for $1 \mathrm{~min}, 54^{\circ} \mathrm{C}$ for $35 \mathrm{~s}$ and $72^{\circ} \mathrm{C}$ for $1,35 \mathrm{~min}$, and final extension of $72^{\circ} \mathrm{C}$ for $7 \mathrm{~min}$.

16S-1 (CCGGTCTGAACTCAGATCAAGT)

HC02198 (TAAACTTCAGGGT- COX1/

GACCAAAAAATCA) Fleas

$95^{\circ} \mathrm{C}$ for $1 \mathrm{~min}, 35$ cycles of $95^{\circ} \mathrm{C}$ for $15 \mathrm{~s}, 55^{\circ} \mathrm{C}$ for $15 \mathrm{~s}$ and $72^{\circ} \mathrm{C}$ for $10 \mathrm{~s}$, and final extension of $72^{\circ} \mathrm{C}$ for $5 \mathrm{~min}$.

LCO1490 (GGTCAACAAAT-

CATAAAGATATTGG)

HepF300 (GTTTCTGACC-

18SrRNA/Hepatozoon TATCAGCTTTCGACG)

HepR900 (CAAATCTAA-

GAATTTCACCTCTGAC)

HEMO1 (TATTGGTTTTAA-

GAACTAATTTTATGATTG)

HEMO2 (CTTCTCCTTCCTT-

TAAGTGATAAGGTTCAC)
$94{ }^{\circ} \mathrm{C}$ for $3 \mathrm{~min}, 35$ cycles of $94^{\circ} \mathrm{C}$ for $30 \mathrm{~s}, 60^{\circ} \mathrm{C}$ for $30 \mathrm{~s}$ and

$72{ }^{\circ} \mathrm{C}$ for $1 \mathrm{~min}$, and final

extension of $72^{\circ} \mathrm{C}$ for $7 \mathrm{~min}$.

$94^{\circ} \mathrm{C}$ for $3 \mathrm{~min}, 35$ cycles of

$94^{\circ} \mathrm{C}$ for $45 \mathrm{~s}, 48^{\circ} \mathrm{C}$ for $60 \mathrm{~s}$ and

$72{ }^{\circ} \mathrm{C}$ for $1 \mathrm{~min}$, and final

extension of $72^{\circ} \mathrm{C}$ for $7 \mathrm{~min}$.
Black and Piesman

(1994)

Folmer et al. (1994)

Ujvari et al. (2004)

Perkins and Keller (2001) was performed with MrBayes 3.1.2 (Ronquist and Huelsenbeck, 2003). Markov chain Monte Carlo (MCMC) simulations were run for $10^{9}$ generations with a sampling frequency of every 100 generations and a burn-in of 25\%. The Maximum-likelihood (ML) analysis was inferred with RAxML-HPC BlackBox 7.6.3 (Stamatakis et al., 2008) (which includes an estimation of bootstrap node support), using 1000 bootstrapping replicates. The best model of evolution was selected by the program jModelTest2 (version 2.1.6) on XSEDE (Darriba et al., 2012), under the Akaike Information Criterion (AIC) (Posada and Buckley, 2004). All phylogenetic analyses were performed using CIPRES Science Gateway (Miller et al., 2010). The trees were examined in Treegraph 2.0.56-381 beta (Stover and Muller, 2010).

Additionally, an analysis of nucleotide polymorphisms of the $18 \mathrm{~S}$ rRNA sequences obtained in the present study was performed. The sequences were aligned using Clustal/W (Thompson et al., 1994) in Bioedit v. 7.0.5.3 (Hall, 1999). The number of haplotypes, haplotype diversity (Hd), nucleotide diversity (Pi) and DNA divergence between populations (group of hosts different species) that were estimated to explore the levels of genetic differentiation among the populations were determined using the program DnaSP 5, version 5.10.01 (Librado and Rozas, 2009).

\section{Results}

A total of 256 animals were captured. One hundred fifty-eight carnivores: Seventy-eight crab-eating foxes, 31 coatis and seven ocelots. One hundred and forty small mammals: 110 wild rodents (77 T. fosteri, 25 0. mamorae and 8C. laticeps) and 30 wild marsupials (14 T. macrurus, $11 \mathrm{G}$. agilis, $4 \mathrm{M}$. domestica and $1 \mathrm{D}$. albiventris). We also sampled blood of 42 domestic dogs.

One thousand five hundred and eighty-two ticks found parasitizing the sampled mammals were collected, of which 1033
(65.2\% [115 adults and 918 nymphs]) belonging to Amblyomma sculptum Berlese species, 241 (15.2\% [ 78 adults and 163 nymphs]) belonging to Amblyomma parvum Aragão species, 32 (2\%) Amblyomma ovale Koch adults, one (0.06\%) Amblyomma tigrinum Koch adult, one (0.06\%) Rhipicephalus (Boophilus) microplus (Canestrini) adult, one (0.06\%) Rhipicephalus sanguineus s.l. (Latreille) adult, four (0.2\%) Amblyomma auricularium (Conil) nymphs, and 269 (17\%) Amblyomma larvae (Table 2). Besides, a total of 80 Polygenis (Polygenis) bohlsi bohlsi (Wagner) fleas were collected. Seventy-five fleas (93.7\%) were collected from 16 (5.4\%) T. fosteri rodents, four $(5 \%)$ from two $(0.6 \%)$ M. domestica, and one $(1.25 \%)$ fleas from one $(0.3 \%)$ specimen of $T$. macrurus.

All 298 DNA animal samples amplified the predicted product for GAPDH gene with an average concentration of 145.3 $(\mathrm{SD}=95,3) \eta \mathrm{G} / \mu \mathrm{L}$, which indicated a successful DNA extraction. The number of tick DNA samples extracted was 523, of which 228 (43.5\%) were from adults, 256 (48.9\%) pooled nymphs and $39(7.4 \%)$ pooled larvae with an average concentration of $45.9(\mathrm{SD}=84,3)$ n.G/ $\mu$ L. Out of 523 sampled ticks, 31 (5.9\% [23 A. parvum adults, $4 A$. sculptum adults, $1 A$. ovale adult, $1 A$. parvum nymph and 2 pooled Amblyomma larvae]) showed negative results for the mitochondrial 16S rRNA tick gene and were excluded from analysis. A total of 39 pooled fleas samples were extracted with an average concentration of $7(S D=8,43) \eta G / \mu L$ and only one sample didn't amplified the predicted product for cox-1 from fleas and was also was excluded from further analysis.

No gamont suggestive of Hepatozoon was found in the blood smears from sampled animals. Out of 298 sampled animals, 61 (78.2\%) crab-eating foxes, 16 (38\%) domestic dogs, five $(71.4 \%)$ ocelots, two (8\%) O. mamorae and one (1.2\%) T. fosteri were positive for 18SrRNA Hepatozoon spp.-PCR based on Perkins and Keller (2001) protocol. Thirty crab-eating foxes samples (38.4\%), 13 (30.9\%) domestic dogs, 13 (41.9\%) coatis, 12 (15.5\%) T. fosteri, 


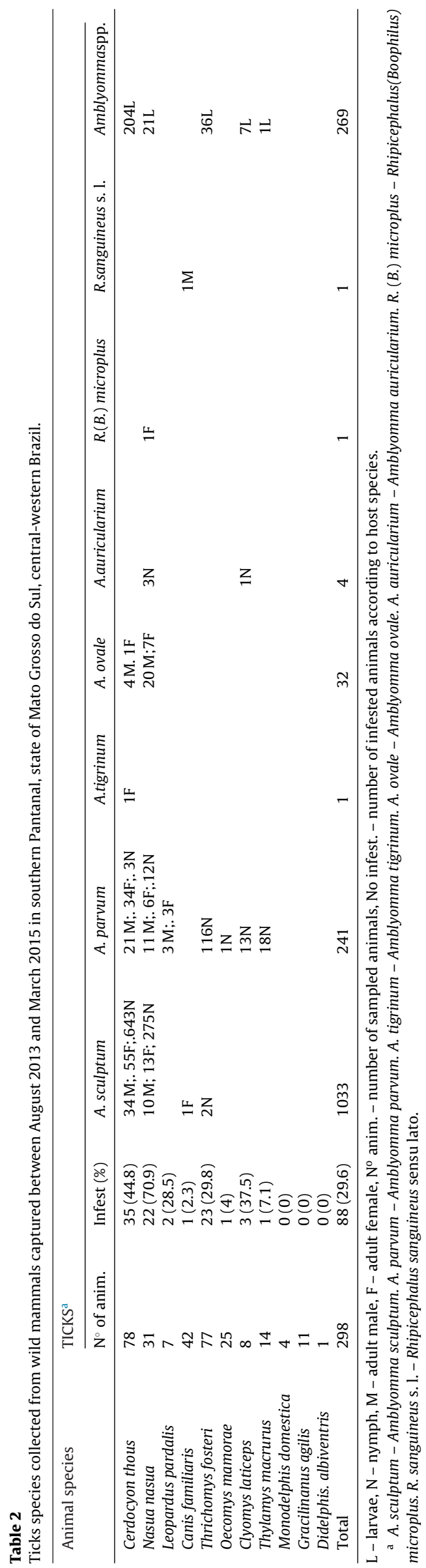

nine (36\%) O. mamorae and one (7.1\%) T. macrurus showed positive results in 18SrRNA Hepatozoon spp.-PCR based on Ujvari et al. (2004) protocol. Twenty (25.6\%) crab-eating foxes and ten (23.8\%) domestic dogs samples showed positive results for both protocols, which allowed the concatenation of obtained sequences. All arthropod (fleas and ticks) DNA samples were negative for both PCR protocols. All sequences obtained from the positive animals were deposited in the international database Genbank under the following accession numbers: KT881500 -KT881535 and KX776286 - KX776408.

All the 18S rRNA Hepatozoon sequences obtained from domestic dogs $(\mathrm{n}=29)$, showed $99-100 \%$ identity ( $100 \%$ of coverage) with H. canis previously deposited in GenBank (AY150067) by BLAST analysis. The $18 \mathrm{~S}$ rRNA Hepatozoon sequences obtained from $C$. thous ( $\mathrm{n}=91$ ) showed $98-99 \%$ identity (97-100\% of coverage) with Hepatozoon spp. sequences obtained from lizards from Portugal (JX531925), H. felis isolate Cuiaba (KM435071) and other H. felis genotype from Japan (AB771501). The sequences amplified from $T$. fosteri spleen samples $(n=13)$ showed $97-99 \%$ identity $(97-100 \%$ of coverage) with Hepatozoon sp. sequence obtained from Crotalus durissus terrificus from Brazil (KC342523) and Hepatozoon fitzsimonsi (KR069084). Additionally, Hepatozoon sequences obtained from 0 . mamorae $(n=11)$ showed $99 \%$ identity $(100 \%$ of coverage) with Hepatozoon sp. sequence amplified from a Brazilian lizard (KM234617) and Hepatozoon spp. sequences amplified from rodents in Brazil (KU667309). The unique 18S rRNA Hepatozoon sequence obtained from $T$. macrurus also showed 99\% identity ( $88 \%$ of coverage) with Hepatozoon spp. sequences amplified from rodents in Brazil (KU667309). The 18S rRNA Hepatozoon sequences obtained from $L$. pardalis sequences $(\mathrm{n}=5)$ and from $N$. nasua ( $\mathrm{n}=12$ ) showed $98-99 \%$ identity (99-100\% of coverage) with $H$. felis isolate Cuiaba (KM435071) and H. felis isolate Japan (AB771501), respectively (Table 3 ).

The phylogenetic tree of Hepatozoon spp. 18S rRNA sequences clustered basically in two large branches: one of them composed by Hepatozoon sequences amplified from C. thous, C. L. familiaris, $N$. nasua and $L$. pardalis from the present study and sequences of $H$. canis, $H$. americanum and $H$. felis retrieved from Genbank. The other large branch grouped: i. Hepatozoon sequences amplified in wild rodents species ( $T$. fosteri and $O$. mamorae) and $T$. macrurus marsupial species from the present study; ii. Hepatozoon sequences amplified from rodents sampled in from Brazil (Mato Grosso and São Paulo, states) and other countries (Chile, Spain, Thailand, Ghana); iii. Hepatozoon sequences amplified from reptiles (snakes, tortoise and lizards) and amphibians previously deposited in Genbank, supported by significant clade support. Adelina sp., Theileria sp., Isospora sp., and Sarcocystis sp. were used as outgroups (Fig. 2).

Nucleotide polymorphisms and DNA divergence between populations (groups of different host species) were also analyzed among the sequences obtained in the present study. The alignments were analyzed in separate, because Perkins and Keller (2001) and Ujvari et al. (2004) PCR protocols amplify different regions of 18SrRNA gene. Both DNA fragments obtained from two different regions from 18SrRNA gene showed to be quite conserved. The analysis of nucleotide polymorphisms of $18 \mathrm{~S}$ rRNA sequences obtained from both protocols showed a small number of haplotypes (4 (Perkins and Keller (2001) PCR protocol) and 7 (Ujvari et al. (2004) protocol)) among the population of different hosts sampled. The alignment of sequences obtained from Ujvari et al. (2004) protocol showed seven haplotypes (haplotype diversity (hd): 0.771 ; Standard Deviation (SD): $=0.032$ ) and nucleotide diversity $(\mathrm{Pi})$ of $0.02084(\mathrm{SD}=0.00142)$. Within the $T$. fosteri group, three different Hepatozoon haplotypes and a noteworthy Pi (0.00813) were observed. Except for the Hepatozoon sequences of rodents, divergence values between sampled host populations, based on the 
Table 3

Maximum identity of 18S rRNA Hepatozoon spp. sequences detected in wild and domestic animals by BLAST analysis.

\begin{tabular}{|c|c|c|c|c|}
\hline Animal species & $\begin{array}{l}\text { Number of } \\
\text { sequences analized }\end{array}$ & Protocol & $\begin{array}{l}\text { \% coverage by } \\
\text { BLAST }^{\oplus}\end{array}$ & $\begin{array}{l}\text { \% identity by } \\
\text { BLAST }^{\circledR}\end{array}$ \\
\hline Canis familiaris & 29 & $\begin{array}{l}\text { Perkins and Keller } \\
\text { (2001) and Ujvari } \\
\text { et al. (2004) }\end{array}$ & $100 \%$ & $\begin{array}{l}\text { 99-100\% H. canis } \\
\text { (AY150067). }\end{array}$ \\
\hline Cerdocyon thous & 14 & $\begin{array}{l}\text { Perkins and Keller } \\
\text { (2001) }\end{array}$ & $97 \%$ & $\begin{array}{l}\text { 98-99\% of identity } \\
\text { with Hepatozoon } \\
\text { spp. from lizards } \\
\text { from Portugal } \\
\text { (JX531925) }\end{array}$ \\
\hline Cerdocyon thous & 47 & $\begin{array}{l}\text { Perkins and Keller } \\
(2001)\end{array}$ & $99-100 \%$ & $\begin{array}{l}\text { 98-99\% H. felis } \\
\text { isolate Cuiaba } \\
\text { (KM435071) }\end{array}$ \\
\hline Cerdocyon thous & 30 & Ujvari et al. (2004) & $100 \%$ & $\begin{array}{l}98 \% \text { H. felis from } \\
\text { Japan (AB771501) }\end{array}$ \\
\hline Thrichomys fosteri & 1 & $\begin{array}{l}\text { Perkins and Keller } \\
(2001)\end{array}$ & $100 \%$ & $\begin{array}{l}\text { 99\% Hepatozoon } \\
\text { spp. from Crotalus } \\
\text { durissus terrificus } \\
\text { from Brazil } \\
(\mathrm{KC} 342523)\end{array}$ \\
\hline Thrichomys fosteri & 12 & Ujvari et al. (2004) & $97-99 \%$ & $\begin{array}{l}\text { 97\% H. fitzsimonsi } \\
\text { (KR069084). }\end{array}$ \\
\hline Oecomys mamorae & 2 & $\begin{array}{l}\text { Perkins and Keller } \\
(2001)\end{array}$ & $100 \%$ & $\begin{array}{l}\text { 99\% Hepatozoon } \\
\text { spp. from a lizard } \\
\text { from Brazil } \\
\text { (KM234617) }\end{array}$ \\
\hline Oecomys mamorae & 9 & Ujvari et al. (2004) & $100 \%$ & $\begin{array}{l}\text { 99\% Hepatozoon } \\
\text { spp. from a rodent } \\
\text { in Brazil } \\
\text { (KU667309) }\end{array}$ \\
\hline Thylamys macrurus & 1 & Ujvari et al. (2004) & $88 \%$ & $\begin{array}{l}\text { 99\% Hepatozoon } \\
\text { spp. from arodent } \\
\text { in Brazil } \\
\text { (KU667309) }\end{array}$ \\
\hline Leopardus. pardalis & 5 & $\begin{array}{l}\text { Perkins and Keller } \\
(2001)\end{array}$ & $98 \%$ & $\begin{array}{l}\text { 98-99\% H. felis } \\
\text { isolate Cuiaba } \\
\text { (KM435071) }\end{array}$ \\
\hline Nasua nasua & 12 & Ujvari et al. (2004) & $99 \%$ & $\begin{array}{l}\text { 98-99\% H. felis } \\
\text { isolate Japan } \\
(\mathrm{AB771501)}\end{array}$ \\
\hline
\end{tabular}

alignment of sequences obtained from Perkins and Keller (2001) PCR protocol, was very low, probably because the alignment generated only four haplotypes (hd: 0.4392 ; SD: 0.048 ) with low number of variable sites (3) to analyze. Although the number of haplotypes found had been small, some differences were observed analyzing the DNA divergence between populations (group of different host species). Analyzing the alignment of 18S rRNA Hepatozoon sequences from both protocols, the Pi value among the rodent populations of $T$. fosteri and $O$. mamorae was high compared to other host species. The alignment of $18 \mathrm{~S}$ rRNA Hepatozoon sequences obtained from Ujvari et al. (2004) protocol showed a high level of divergence between the haplotypes found in domestic dogs and $T$. fosteri rodents groups $(\mathrm{Pi}=0.04293$ ). Additionally, the $\mathrm{Pi}$ value ( 0.0074$)$ found between the $18 \mathrm{~S}$ rRNA Hepatozoon sequences obtained from $N$. nasua and $C$. thous populations was lower in relation to other host species.

\section{Discussion}

The present study showed the presence of Hepatozoon spp. in blood or spleen samples of wild carnivorous, domestic dogs, rodents and marsupials in the region of Pantanal, state of Mato Grosso do Sul, central-western Brazil. Molecular analyses based on 18S rRNA gene revealed a high occurrence of Hepatozoon spp. among sampled animals.

Five out seven free-living ocelots captured showed to be positive for Hepatozoon spp. The occurrence of Hepatozoon was higher (83.3\%) than that reported by Metzger et al. (2008) in wild $L$. pardalis $(17.2 \%)$ sampled in the states of Maranhão and Ceará, northeastern Brazil. Based on the phylogenetic analysis, three $18 \mathrm{~S}$ rRNA Hepatozoon sequences detected in sampled $L$. pardalis and sequences previously detected in wild felids from northeastern Brazil (Metzger et al., 2008) were closely related to Hepatozoon sp. genotype from Spanish cats. A genotype closely related to Hepatozoon sp. isolated from Spanish cats has also been found in a pampas gray fox (Lycalopex gymnocercus) that was co-infected with canine distemper virus in Argentina (Giannitti et al., 2012). The gray fox was euthanized after had showed severe incoordination; on necropsy, Hepatozoon cysts were observed in skeletal and myocardium muscles. Keeping in mind that this genotype closely related to $H$. felis is circulating in Brazil, more studies are much needed in order to monitor the impact of this parasite among the Brazilian wildlife.

The occurrence of Hepatozoon spp. among sampled crab-eating foxes found in the present study was very high (91\%) when compared to previous studies, which had found percentages of positivity of $43.1 \%$ in wild C. thous sampled in the state of Espírito Santo, southeastern Brazil (Almeida et al., 2013), and 55\% in wild C. thous sampled in the state of Rio Grande do Sul, southern Brazil (Criado-Fornelio et al., 2006). The phylogenetic analysis demonstrated that the Hepatozoon genotype infecting crab-eating foxes in the region of Pantanal was closely related to Hepatozoon spp. Isolate Curupira 2, an $H$. americanum-related organism, and $H$. americanum. The $H$. americanum-related haplotypes have been reported in crab-eating foxes from the Brazilian states of Rio Grande do Sul (Criado-Fornelio et al., 2006), São Paulo (André et al., 2010), and Espírito Santo (Almeida et al., 2013). Thus, this haplotype appears to be common among foxes in Brazil. Although H. americanum is 


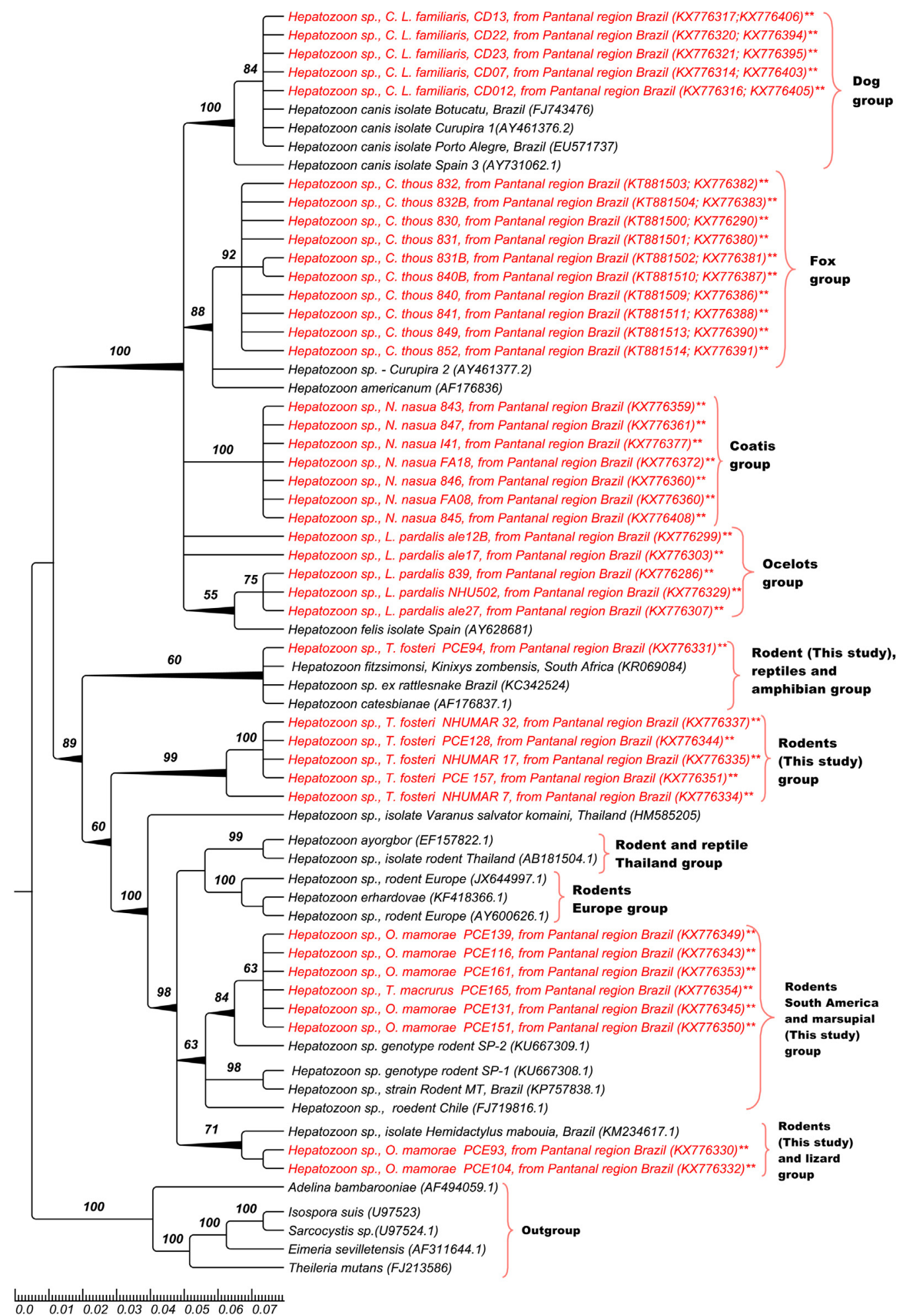

Fig. 2. Phylogenetic tree based on an alignment of $1900 \mathrm{bp}$ fragment of Hepatozoon spp. $18 \mathrm{SrRNA}$ sequences, using Bayesian inference (BI) method and GTR $+\mathrm{G}+\mathrm{I}$ evolutionary model. Numbers at nodes correspond to Bayesian posterior probabilities over 50 .

considered a high pathogenic protozoa species for domestic dogs in the United States (Mathew et al., 1998), the H. americanum-related haplotype-infected crab-eating foxes in Brazil were apparently healthy (Criado-Fornelio et al., 2006; André et al., 2010; Almeida et al., 2013).

Hepatozoon canis infection was more prevalent (43.2\%) among domestic dogs sampled in the present study than in dogs (3.63\%) from urban areas from the same state of Mato Grosso do Sul, Brazil (Ramos et al., 2015). The higher prevalence of $H$. canis among dogs from rural areas when compared to dogs from urban areas has been already reported in several states from Brazil (Rubini et al., 2008; Gomes et al., 2010; Ramos et al., 2010; Miranda et al., 2014; Ramos et al., 2015). The phylogenetic positioning reinforced the hypothe- 
sis that the domestic dogs from rural areas in Brazil are commonly infected by $H$. canis (Miranda et al., 2014).

To the best of authors' knowledge, the present study reported the first molecular detection of Hepatozoon spp. among coatis. Although Rodrigues et al. (2007) had previously detected Hepatozoon in two coatis from the state of Minas Gerais, southeastern Brazil, the diagnosis relied only on morphological and morphometric features of gametocytes in blood-stained smears. The Hepatozoon sequences detected in coatis were grouped within the large branch composed by the closely related $H$. canis, $H$. americanum and $H$. felis sequences. Similarly, Hepatozoon detected in raccoons (Procyon lotor), another member of Procyonidae family from the United States, showed to be closely related to $H$. canis (Allen et al., 2011). Considering that coatis can represent preys for wild felids (Novack et al., 2005), future studies should be performed in order to investigate the role of coatis as source of Hepatozoon infection for wild carnivores in Pantanal biome.

Although Hepatozoon spp. oocysts have been found in A. ovale (Rubini et al., 2009) and R. (B.) microplus (Miranda et al., 2011) ticks hemocoel, only $A$. ovale has been showed to be a competent vector for Hepatozoon in Brazil (Rubini et al., 2009; Demoner et al., 2013). In the present study, no tick, even A. ovale, was positive for Hepatozoon spp. Similar results have been found in northern Pantanal (Melo et al., 2016), where only one (1/930) A. sculptum was positive for Hepatozoon spp. Similarly, H. canis oocysts were found in only one (1/31) R. (B.) microplus ticks' hemocoel in an endemic area for canine hepatozoonosis in southeastern Brazil (Demoner et al., 2016). In fact, both A. sculptum and $R$. microplus species seem to show little or no importance in the hepatozoonosis epidemiology (Demoner et al., 2013; Demoner et al., 2016). Although the role of fleas as invertebrate hosts for Hepatozoon species infecting rodents in the United States have been proposed by Watkins et al. (2006), the $P$. (P.) b. bohlsi fleas collected from rodents in the present study did not show positivity for Hepatozoon in the molecular assays. Also, the role of other transmission routes, such as transplacental and predation, and the participation of different arthropods species as source of Hepatozoon infection should be better investigated in endemic areas.

The prevalence of Hepatozoon among wild rodents ( $T$. fosteri and 0 . mamorae) was $21.8 \%(n=24 / 110)$, lower than that reported $(55.2 \%)$ in rodents (O. nigripes, O. flavescens, Akodon sp., Necromys lasiurus and Sooretamys angouya) sampled in an endemic area for canine hepatozoonosis in the state of São Paulo state, southeastern Brazil (Demoner et al., 2016). However, the found prevalence was higher than that reported (7.1\%) in C. callosus rodents from northern Pantanal, state of Mato Grosso (Wolf et al., 2016). Although Hepatozoon DNA has been detected in wild rodents from Brazil (Demoner et al., 2016; Wolf et al., 2016), this is the first molecular detection of this parasite in $T$. fosteri and $O$. mamorae rodents and in $T$. macrurus marsupial in Brazil.

Although the transmission of $H$. americanum has been experimentally confirmed by the ingestion of cysts containing - rodent tissues by dogs (Johnson et al., 2009), previous studies showed evidence that the Hepatozoon species found in free-living rodents in Brazil differ from those detected in domestic and wild canids (Maia et al., 2014; Demoner et al., 2016). Herein, the phylogenetic positioning and DNA divergence analysis reinforce the hypothesis that the transmission of Hepatozoon from preys (rodents) to canids is a rare event and may not contribute to the spread of the parasite among canids in Brazil (Maia et al., 2014; Demoner et al., 2016).

Although the transmission of Hepatozoon spp. by carnivorism has been well documented in systems involving snakes as intermediate hosts, and frogs or lizards as paratenic hosts (Smith, 1996; Smith et al., 1999), Sloboda et al. (2008) showed that snakes could get experimentally infected by feeding tissues from Hepatozooninfected rodents. Furthermore, Allen et al. (2011) and Demoner et al. (2016) detected Hepatozoon-rodent sequences closely related to Hepatozoon-reptile sequences. In addition to this, monozoic cysts containing cystozoites have been recently found in the lung of a free-living wild rodent sampled in the state of São Paulo State, Brazil (Demoner et al., 2016). Herein, the phylogenetic positioning of Hepatozoon detected in wild rodents suggested a possible transmission of Hepatozoon species between rodents and reptiles and amphibians by predation. Further studies focusing on the detection of monozoic cysts in rodents' tissues should be performed in order to support this hypothesis.

Although the Hepatozoon fragments obtained from two 18SrRNA different regions were quite conserved, nucleotide polymorphisms and DNA divergence between populations (groups of different host species) were observed in the present study. The present study provided some novel data concerning the Hepatozoon spp. diversity in Brazil. Within the $T$. fosteri group, three different Hepatozoon haplotypes and a noteworthy Pi value (0.00813) were observed. In addition to this, the Pi value found among the rodent populations of $T$. fosteri and O. mamorae was higher than that found among other host species, suggesting some degree of Hepatozoon genetic diversity among the population of wild rodents from Brazil. This fact may be due to the diversity of hosts (rodents, reptiles and amphibians) sharing the same closely related Hepatozoon species, revealed by the phylogenetic analysis.

In conclusion, the present study showed a high occurence of Hepatozoon spp. among wild animals in southern Pantanal region, Brazil. Carnivores, rodents and domestic dogs seemed not to share the same Hepatozoon species in the studied region. Rodents may play a role in the routes of Hepatozoon transmission to reptiles and amphibians. An evidence of some degree of Hepatozoon genetic diversity among the population of wild rodents from Brazil was reported for the first time.

\section{Acknowledgments}

We are thankful to Fundação de Amparo à Pesquisa do Estado de São Paulo (FAPESP) and Conselho Nacional de Desenvolvimento Científico e Tecnológico (CNPq) for the financial support to M.R. André (Process numbers \#2015/14896-1 and 473575/2014-0, respectively) and for Doctorate Scholarship to K. C. M Sousa (Process \#2013/13186-5) and the Scientific Initiation Fellowship to M. P. Fernandes (Process \#2016/10676-0).

\section{Appendix A. Supplementary data}

Supplementary data associated with this article can be found, in the online version, at http://dx.doi.org/10.1016/j.vetpar.2017.02. 023.

\section{References}

Allen, K.E., Yabsley, M.J., Johnson, E.M., Reichard, M.V., Panciera, R.J., Ewing, S.A., Little, S.E., 2011. Novel Hepatozoon in vertebrates from the southern United States. J. Parasitol. 97, 648-653.

Almeida, A.P., Souza, T.D., Marcili, A., Labruna, M.B., 2013. Novel Ehrlichia and Hepatozoon agents infecting the crab-eating fox (Cerdocyon thous) in southeastern Brazil. J. Med. Entomol. 50 (3), 640-646.

Altschul, S.F., Gish, W., Miller, W., Myers, E.W., Lipman, D.J., 1990. Basiclocalalignment search tool. J. Mol. Biol. 215, 403-410.

Alves, F.M., de Lima, J.S., Rocha, F.L., Herrera, H.M., Mourão, G.M., Jansen, A.M., 2016. Complexity and multi-factoriality of Trypanosoma cruzi sylvatic cycle in coatis, Nasua nasua (Procyonidae), and triatomine bugs in the Brazilian Pantanal. Parasites Vectors 9 (1), 378.

André, M.R., Adania, C.H., Teixeira, R.H., Vargas, G.H., Falcade, M., Sousa, L., Salles, A.R., Allegretti, S.M., Felippe, P.A., Machado, R.Z., 2010. Molecular detection of Hepatozoon spp. in Brazilian and exotic wild carnivores. Vet. Parasitol. 173 (1-2), 134-138.

Baneth, G., Aroch, I., Tal, N., Harrus, S., 1998. Hepatozoon species infection in domestic cats: a retrospective study. Vet. Parasitol. 79 (2), 123-133. 
Baneth, G., Sheiner, A., Eyal, O., Hahn, S., Beaufils, J.P., Anug, Y., Talmi-Frank, D., 2013. Redescription of Hepatozoon felis (Apicomplexa: Hepatozoidae) based on phylogenetic analysis, tissue and blood form morphology, and possible transplacental transmission. Parasites Vectors 102 (6), 2-10.

Bell, T.G., Kramvis, A., 2013. Fragment merger: an online tool to merge overlapping long sequence fragments. Viruses 5, 824-833.

Benson, D.A., Mizrachi, I.K., Lipman, D.J., Ostell, J., Rapp, B.A., Wheeler, D.I., 2002. GenBank. Nucleic Acids Res. 30, 17-20.

Birkenheuer, A.J., Levy, M.G., Breitschwerdt, E.B., 2003. Development andevaluation of a seminested PCR for detection and differentiation os Babesia gibsoni (Asian genotype) and B. canis DNA in canine blood samples. J. Clin. Microbiol. 41, 4172-4177.

Black, W.C., Piesman, J., 1994. Phylogeny of hard- and soft-tick taxa (Acari: ixodida) based on mitochondrial 16S rDNA sequences. Proc. Natl. Acad. Sci. 91 (21) 10034-10038.

Bonvicino, C.R., Lemos, B., Weksler, M., 2005. Small mammals of Chapada dos Veadeiros National Park (Cerrado of Central Brazil): ecologic, karyologic, and taxonomic considerations. Braz. J. Biol. 65, 395-406.

Criado-Fornelio, A., Ruas, J.L., Casado, N., Farias, N.A., Soares, M.P., Müller, G., Brumt, J.G., Berne, M.E., Buling-Saraña, A., Barba-Carretero, J.C., 2006. New molecular data on mammalian Hepatozoon species (Apicomplexa: adeleorina) from Brazil and Spain. J. Parasitol. 92 (1), 93-99.

Darriba, D., Taboada, G.L., Doalho, R., Posada, D., 2012. jModelTest 2: more models,new heuristics and parallel computing. Nat. Methods 9, 772.

Davis, D.S., Robinson, R.M., Craig, T.M., 1978. Naturally occurring hepatozoonosis in a coyote. J. Wildl. Dis. 14 (2), 244-246.

Demoner, L.C., Rubini, A.S., Paduan, K.S., Metzger, B., de Paula Antunes, J.M., Martins, T.F., Mathias, M.I., O'Dwyer, L.H., 2013. Investigation of tick vectors of Hepatozoon canis in Brazil. Ticks Tick Borne Dis. 4 (6), 542-546.

Demoner, L.C., Magro, N.M., da Silva, M.R., de Paula Antunes, J.M., Calabuig, C.I., O'Dwyer, L.H., 2016. Hepatozoon spp. infections in wild rodents in an area of endemic canine hepatozoonosis in southeastern Brazil. Ticks Tick Borne Dis. 7 (5), 859-864

East, M.L., Wibbelt, G., Lieckfeldt, D., Ludwig, A., Goller, K., Wilhelm, K., Schares, G., Thierer, D., Hofer, H., 2008. A Hepatozoon species genetically distinct from $\mathrm{H}$. canis infecting spotted hyenas in the Serengeti ecosystem, Tanzania. J. Wildi. Dis. 44 (1), 45-52.

Ewing, B., Hillier, L., Wendl, M.C., Green, P., 1998. Base-calling of automated sequencer traces using phred. I. Accuracy assessment. Genome Res. 8 (3), $175-185$

Fayer, R., Dubey, J.P., Lindsay, D.S., 2004. Zoonotic protozoa: from land to sea. Trends Parasitol. 20 (11), 531-536.

Folmer, O., Black, M., Hoeh, W., Lutz, R., Vrijenhoek, R., 1994. DNA primers for amplification of mitochondrial cytochrome c oxidase subunit I from diverse metazoan invertebrates. Mol. Mar. Biol. Biotechnol. 3, 294-299.

Forlano, M., Scofield, A., Elisei, C., Fernandes, K.R., Ewing, S.A., Massard, C.L., 2005 Diagnosis of Hepatozoon spp. in Amblyomma ovale and its experimental transmission in domestic dogs in Brazil. Vet. Parasitol. 134, 1-7.

Garrett, J.J., Kocan, A.A., Reichard, M.V., Panciera, R.J., Bahr, R.J., Ewing, S.A., 2005 Experimental infection of adult and juvenile coyotes with domestic dog and wild coyote isolates of Hepatozoon americanum (Apicomplexa: adeleorina). J Wildl. Dis. 41 (3), 588-592

Giannitti, F., Diab, S.S., Uzal, F.A., Fresneda, K., Rossi, D., Talmi-Frank, D., Baneth, G. 2012. Infection with a Hepatozoon sp. closely related to Hepatozoon felis in a wild Pampas gray fox (Lycalopex -Pseudalopex - gymnocercus) co-infected with canine distemper virus. Vet. Parasitol. 186, 497-502.

Gomes, P.V., Mundim, M.J.S., Mundim, A.V., de Ávila, D.F., Guimarães, E.C., Cury, M.C., 2010. Occurrence of Hepatozoon sp: in dogs in the urban area originating from a municipality in southeastern Brazil. Vet. Parasitol. 175, 155-161.

Guimarães, J.H., Tucci, E.C., Barros-Batttesti, D.M., 2001. Ectoparasitos De Importância Veterinária. Editora Plêiade, São Paulo, Brasil, 13 pp.

Hall, T.A., 1999. BioEdit: a user-friendly biological sequence alignment editor and analysis program for Windows 95/98/NT. Nucl. Acids Symp. Ser. 41, 95-98.

Harris, D.J., Borges-Nojosa, D.M., Maia, J.P., 2015. Prevalence and diversity of hepatozoon in native and exotic geckos from Brazil. J. Parasitol. 101 (1), 80-85.

Johnson, E.M., Allen, K.E., Panciera, R.J., Ewing, S.A., Little, S.E., Reichard, M.V., 2007. Field survey of rodents for Hepatozoon infections in an endemic focus of American canine hepatozoonosis. Vet. Parasitol. 150, 27-32.

Johnson, E.M., Panciera, R.J., Allen, K.E., Sheets, M.E., Beal, J.D., Ewing, S.A., Little S.E., 2009. Alternate pathway of infection with Hepatozoon americanum and the epidemiologic importance of predation. J. Vet. Intern. Med. 23, 1315-1318.

Katoh, K., Standley, D.M., 2013. MAFFT multiple sequence alignment software version 7: improvements in performance and usability. Mol. Biol. Evol. 30 $772-780$

Kocan, A.A., Cummings, C.A., Panciera, R.J., Mathew, J.S., Ewing, S.A., Barker, R.W., 2000. Naturally occurring and experimentally transmitted Hepatozoon americanum in coyotes from Oklahoma. J. Wildl. Dis. 36 (1), 149-153.

Kubo, M., Miyoshi, N., Yasuda, N., 2006. Hepatozoonosis in two species of Japanese wild cats. J. Vet. Med. Sci. 68, 833-837.

Leal, D.D., Dreyer, C.S., da Silva, R.J., Ribolla, P.E., Paduan K. dos, S., Bianchi, I., O'Dwyer, L.H., 2015. Characterization of Hepatozoon spp. in Leptodactylus chaquensis and Leptodactylus podicipinus from two regions of the Pantanal, state of Mato Grosso do Sul, Brazil. Parasitol. Res. 114, 1541-1549.

Leary, W., Underwood, R., Anthony, S., Cartner, D., Corey, T., Grandin, C.B. Greenacre, S., Gwaltney-Bran, M.A., McCrackin, R. Meyer, 2013. AVMA
Guidelines for the Euthanasia of Animals (2013 Edition). American Veterinary Medical Association, Schaumburg IL.

Librado, P., Rozas, J., 2009. DnaSP v5: a software for comprehensive analysis of DNA polymorphism data. Bioinformatics 25, 1451-1452.

Linardi, P.M., Guimarães, L.R., 2000. Sifonápteros Do Brasil. Museude Zoologia USP/FAPESP, São Paulo.

Maia, J.P., Álvares, F., Boratýnski, Z., Brito, J.C., Leite, J.V., Harris, J., 2014. Molecular assessment of Hepatozoon (Apicomplexa: adeleorina) infections in wild canids and rodents from North Africa, with implications for transmission dynamics across taxonomic groups. J. Wildl. Dis. 50 (4), 837-848.

Malheiros, J., Costa, M.M., do Amaral, R.B., de Sousa, K.C., André, M.R., Machado, R.Z., Vieira, M.I., 2016. Identification of vector-borne pathogens in dogs and cats from Southern Brazil. Ticks Tick Borne Dis. 7, 893-900.

Martins, T.F., Onofrio, V.C., Barros-Battesti, D.M., Labruna, M.B., 2010. Nymphs of the genus Amblyomma (Acari Ixodidae) of Brazil: descriptions, redescriptions, and identification key. Ticks Tick-Borne Dis. 1, 75-99.

Martins, T.F., Barbieri, A.R., Costa, F.B., Terassini, F.A., Camargo, L.M., Peterka, C.R., de, C., Pacheco, R., Dias, R.A., Nunes, P.H., Marcili, A., Scofield, A., Campos, A.K. Horta, M.C., Guilloux, A.G., Benatti, H.R., Ramirez, D.G., Barros-Battesti, D.M., Labruna, M.B., 2016. Geographical distribution of Amblyomma cajennense (sensu lato) ticks (Parasitiformes: ixodidae) in Brazil, with description of the nymph of A. cajennense (sensu stricto). Parasite Vectors 9, 186

Mathew, J.S., Ewing, S.A., Panciera, R.J., Woods, J.P., 1998. Experimental transmission of Hepatozoon americanum Vincent-Johnson, et al., 1997 to dogs by the Gulf Coast tick, Amblyomma maculatum Koch. Vet. Parasitol. 80 (1), 1-14.

Melo, A.L.T., Witter, R., Martins, T.F., Pacheco, T.A., Alves, A.S., Chitarra, C.S., Dutra, V., Nakazato, L., Pacheco, R.C., Labruna, M.B., Aguiar, D.M., 2016. A survey of tick-borne pathogens in dogs and their ticks in the Pantanal biome, Brazil. Med. Vet. Entomol. 30, 112-116.

Miller, M.A., Pfeiffer, W., Schwartz, T., 2010. Creating the CIPRES Science Gateway for inference of large phylogenetic trees. Proceedings of the Gateway Computing Environments Workshop (GCE), 1-8.

Miranda, R.L., Castro, J.R., Olegário, M.M.M., Beletti, M.E., Mundim, A.V., O’Dwyer, L.H., Eyal, O., Talmi-Frank, D., Cury, M.C., Baneth, G., 2011. Oocysts of Hepatozoon canis in Rhipicephalus (Boophilus) microplus collected from a naturally infected dog. Vet. Parasitol. 177, 392-396.

Miranda, R.L., O'Dwyer, L.H., de Castro, J.R., Metzger, B., Rubini, A.S., Mundim, A.V., Eyal, O., Talmi-Frank, D., Cury, M.C., Baneth, G., 2014. Prevalence andmolecular characterization of Hepatozoon canis in dogs from urban and ruralareas in Southeast Brazil. Res. Vet. Sci. 97, 326-329.

Novack, A.J., Main, M.B., Sunquist, M.E., Labisky, R.F., 2005. Foraging ecology of jaguar (Panthera onca) and puma (Puma concolor) in hunted and non-hunted sites within the Mayan Biosphere Reserve, Guatemala. J. Zool. 267, 178-197.

O’Dwyer, L.H., Moço, T.C., Paduan, K. dos S., Spenassatto, C., da Silva, R.J., Ribolla, P.E., 2013. Description of three new species of Hepatozoon (Apicomplexa, Hepatozoidae) from Rattlesnakes (Crotalus durissus terrificus) based on molecular, morphometric and morphologic characters. Exp. Parasitol. 135 (2), 200-207.

O’Dwyer, 2011. Brazilian canine hepatozoonosis. Rev. Bras. Parasitol. Vet. 20 (3), 181-193.

Perkins, S.L., Keller, A.K., 2001. Phylogeny of nuclear small subunit rRNA genes of hemogregarines amplified with specific oligonucleotídeos. J. Parasitol. 87, 870-876.

Posada, D., Buckley, T.R., 2004. Model selection and model averaging in phylogenetics: advantages of akaike information criterion and bayesian approaches over likelihood ratio tests. Syst. Biol. 53, 793-808.

Ramos, R., Ramos, C., Araújo, F., Oliveira, R., Souza, I., Pimentel, D., Galindo, M., Santana, M., Rosas, E., Faustino, M., Alves, L., 2010. Molecular survey andgenetic characterization of tick-borne pathogens in dogs in metropolitanRecife (north-eastern Brazil). Parasitol. Res. 107, 1115-1120.

Ramos, C.A., Babo-Terra, V.J., Pedroso, T.C., Souza Filho, A.F., de Araújo, F.R. Cleveland, H.P., 2015. Molecular identification of Hepatozoon canis in dogs from campo grande, mato grosso do sul, Brazil. Rev. Bras. Parasitol. Vet. 24 (2), 247-250.

Rodrigues, A.F.S.F., Daemon, E., Massard, C.L., 2007. Morphological and morphometrical characterization of gametocytes of Hepatozoon procyonis Richards, 1961 (Protista, Apicomplexa) from a Brazilian wild procionid Nasuc nasua and Procyon cancrivorus (Carnivora, Procyonidae). Parasitol. Res. 100, 347-350.

Ronquist, F., Huelsenbeck, J.P., 2003. MrBayes 3: Bayesian phylogenetic inference under mixed models. Bioinformatics 19 (12),1572-1574.

Rubini, A.S., Paduan, K.S., Lopes, V.V.A., O’Dwyer, L.H., 2008. Molecular and parasitological survey of Hepatozoon canis (Apicomplexa Hepatozoidae) indogs from rural area of São Paulo state, Brazil. Parasitol. Res. 102, 895-899.

Rubini, A.S., Paduan, K.S., Martins, T.F., Labruna, M.B., O’Dwyer, L.H., 2009 Acquisi-tion and transmission of Hepatozoon canis (Apicomplexa: hepatozoidae) by thetick amblyomma ovale (Acari: ixodidae). Vet. Parasitol. $164,324-327$

Sanger, F., Nicklen, S., Coulson, A.R., 1977. DNA sequencing with chain-terminating inhibitors. Proc. Natl. Acad. Sci. U. S. A. 74 (12), 5463-5467.

Sikes, R.S., Gannon, W.L., 2011. Guidelines of the American Society of Mammalogists for the use of wild mammals in research. J. Mammal. 92, 235-253.

Sloboda, M., Kamler, M., Bulantová, J., Votypka, J., Modry, T.G., 2008. Rodents as intermediate hosts of Hepatozoon ayorgbor (Apicomplexa: 
adeleina:hepatozoidae) from the African ball python, Python regius? Folia Parasitol. 55, 13-16.

Smith, T.G., Kim, B., Desser, S.S., 1999. Phylogenetic relationships among Hepatozoon species from snakes, frogs and mosquitoes of Ontario Canada,determined by ITS-1 nucleotide sequences and life-cycle, morphological and developmetal characteristics. Int. J. Parasitol. 29, 293-304.

Smith, T.G., 1996. The genus Hepatozoon (Apicomplexa: adeleina). J. Parasitol. 82 (4), 565-585.

Stamatakis, A., Hoover, P., Rougemont, J., 2008. A rapid bootstrap algorithm for the RAxML Web servers. Syst. Biol. 57 (5), 758-771.

Stover, B.C., Muller, K.F., 2010. TreeGraph 2: Combining and visualizing evidence from different phylogenetic analyses. BMC Bioinf. 11 (7), 1-9.

Thompson, J.D., Higgins, D.G., Gibson, T.J., 1994. CLUSTAL W: improving the sensitivity of progressive multiple sequence alignment through sequence weighting, position specific gap penalties and weight matrix choice. Acids Res. 22, 1673-4680.

Ujvari, B., Madsen, T., Olsson, M., 2004. High prevalence of Hepatozoon spp (Apicomplexa, Hepatozoidae) infection in water pythons (Liasis fuscus) from tropical Australia. J. Parasitol. 90 (3), 670-672.
Viana, L.A., Paiva, F., Coutinho, M.E., Lourenço-de-Oliveira, R., 2010. Hepatozoon caimani (Apicomplexa: hepatozoidae) in wild caiman, Caiman yacare, from the pantanal region, Brazil. J. Parasitol. 96 (1), 83-88.

Watkins, R.A., Moshier, S.E., Aelita, J.P., 2006. The flea, megabothrisabantis: an invertebrate host of hepatozoon sp. and a likely definitive host in hepatozoon infections of the montane vole, microtus montanus. J. Wildl. Dis. 42 (2), 386-390.

Wobeser, G.A., 2007. Disease in Wild Animals: Investigation and Management. Springer Berlin Heidelberg, Berlin, German, pp. 393.

Wolf, R.W., Aragona, M., Muñoz-Leal, S., Pinto, L.B., Melo, A.L.T., Braga, I.A., Costa, J.D.S., Martins, T.F., Marcili, A., Pacheco, R.D.C., Labruna, M.B., Aguiar, D.M., 2016. Novel Babesia and Hepatozoon agents infecting non-volant small mammals in the Brazilian Pantanal, with the first record of the tick Ornithodoros guaporensis in Brazil. Ticks Tick-Borne Dis. 7, 449-456.

Metzger, B., dos Santos Paduan, K., Rubini, A.S., de Oliveira, T.G., Pereira, C., O’Dwyer, L.H., 2008. The first report of Hepatozoon sp: (Apicomplexa: hepatozoidae) in neotropical felids from Brazil. Vet. Parasitol. 152 (1-2), 28-33.

Wozniak, E.J., Kazacos, K.R., Telford, J.R., Mcclaughlin, G.L., 1995. Characterization of the clinical and anatomical pathological changes associated with Hepatozoon mocassini infections in unnatural reptilian hosts. Int. J. Parasitol. 26, 141-146. 